\title{
Development and Validation of UV-Spectrophotometric Method for Estimation of Metformin in Bulk and Tablet Dosage Form
}

\author{
Yuvraj Dilip Dange ${ }^{1}$, Sandip Mohan Honmane ${ }^{*}$, Somnath Devidas Bhinge ${ }^{2}$, Vijay Rajaram Salunkhe ${ }^{2}$, \\ Dhanraj Raghunath Jadge ${ }^{1}$
}

${ }^{1}$ Department of Pharmaceutics, Annasaheb Dange College of Pharmacy, Ashta, Shivaji University, Kolhapur, Maharashtra, INDIA. ${ }^{2}$ Department of Pharmaceutical Chemistry, Rajarambapu College of Pharmacy, Kasegaon, Shivaji University, Kolhapur, Maharashtra, INDIA.

\begin{abstract}
Introduction: Diabetes mellitus, a metabolic disorder characterized by increased blood sugar level. Metformin hydrochloride is used to treat type I Diabetes mellitus. Metformin hydrochloride chemically 1, 1-dimethylbiguanide hydrochloride, is white crystalline powder, hygroscopic and freely soluble in water, Officially UV spectrophotometric method used for estimation of Metformin Hydrochloride from the bulk and tablets formulations. Objective: Develop and validate a simple, rapid, accurate, economic and precise UV/VIS method for Metformin Hydrochloride in bulk and tablets formulation. Methodology: Choices of a common solvent were essential so various solvent ranges including methanol, ethanol, acetonitrile and phosphate buffer and various concentrations ranges of various buffers were analyzed. Conclusion: Among different solvents water has showed better results, hence water was selected as a solvent for the proposed method. Metformin Hydrochloride showed maximum absorbance at $234 \mathrm{~nm}$. The percentage recoveries for Metformin Hydrochloride were found in the range of 99$101 \%$. Method was quantitatively evaluated in terms of linearity, accuracy, precision, ruggedness, robustness and recovery. The method was simple, convenient and suitable for the determination of Metformin Hydrochloride from bulk and tablet dosage forms.
\end{abstract}

Key Words: Metformin $\mathrm{HCl}$, UV-Spectrophotometry, Tablet.

\section{INTRODUCTION}

Chemically Metformin Hydrochloride $(\mathrm{HCl})$ is a $(N, N$-dimethyl imidodicarbonimidic diamide monohydrochloride as shown in Figure 1. Metformin $\mathrm{HCl}$ is used in the treatment of diabetic's mellitus-II, which works to decrease the glucose absorption in the small intestine, increase of glucose transport into cells, decrease the plasma frees fatty acid concentrations and inhibition of gluconeogenesis. Activation of AMPK plays a vital role in these processes. ${ }^{1,2}$

Literature survey revealed that reports on analytical methods such as UV-Visible, HPLC, LC-MS, LC-MS/MS and HPTLC for the determination of Metformin $\mathrm{HCl}$ from the bulk and dosage form, very few analytical methods reported for Metformin
$\mathrm{HCl}^{3-18}$ Moreover reported methods were not much cost-effective in terms of solvent consumption. The present investigation was carried out in the view of establishing a simple, rapid, accurate, economic, precise and robust UV method for estimation Metformin $\mathrm{HCl}$ in bulk and tablet dosage form using water as the solvent.

\section{MATERIALS AND METHODS ${ }^{19,20,21}$ Instrument \\ A Shimadzu UV-1800 240V UV/VIS spectrophotometer was used having two matched $1 \mathrm{~cm}$ matches quartz cell.}

Submission Date: 29-08-2017; Revision Date: 14-09-2017; Accepted Date: 04-10-2017

DOI: 10.5530/ijper.51.4s.109 Correspondence: Mr. Sandip Mohan Honmane, Annasaheb Dange College of Pharmacy, Ashta, Shivaji University, Kolhapur-416301. Maharashtra, INDIA. Phone no: 918600392878 E-mail: sandiphonmane@ gmail.com

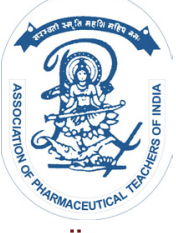

www.ijper.org 


\section{Chemical and reagents}

All the reagents and solvents were of analytical grade high purity deionized water was obtained from Millipore, Milli-Q (Bedford, MA, USA) purification system. Metformin $\mathrm{HCl}$ was purchased from Pawar supplier Karad, Maharashtra, India. All other chemicals used were of analytical grade.

\section{Preparation of Standard Stock Solutions}

$100 \mathrm{mg}$ of Metformin HCL was weighed separately and transferred in $100 \mathrm{~mL}$ volumetric flasks. The drugs were dissolved in $50 \mathrm{~mL}$ of distilled water by sonication and then the volume was made up to the mark with the same solvent to obtain final concentration $1000 \mu \mathrm{g} \mathrm{mL} \mathrm{m}^{-1}$ of the component.

\section{Sample Solution}

Powder of twenty tablets (Marketed tablets of metformin; Bigomet), containing $500 \mathrm{mg}$ Metformin $\mathrm{HCl}$, was weighed. A quantity of powder equivalent to $10 \mathrm{mg}$ of Metformin $\mathrm{HCl}$ was taken in different $10 \mathrm{~mL}$ volumetric flasks containing about $5 \mathrm{~mL}$ distilled water for analysis and sonicated for $15 \mathrm{~min}$. After sonication, the volume was made up to the mark with the same solution to obtain sample stock solution of Metformin $\mathrm{HCl}\left(1000 \mathrm{mg} \mathrm{mL}^{-1}\right)$. Further, $0.010 \mathrm{~mL}$ solution was quantitatively transferred to a $10 \mathrm{~mL}$ volumetric flask to get final concentration $10 \mathrm{mg} \mathrm{mL}^{-1}$ Metformin $\mathrm{HCl}$. The resulting solution was used for absorbance and results were recorded.

\section{Preparation of Working Standard Solution}

Suitable aliquots of $1000 \mathrm{mg} \mathrm{mL}^{-1}$ solution were diluted up to the mark with water to get the concentration range of 10, 20, 30, 40 and $50 \mathrm{mg} \mathrm{mL}^{-1}$ for Metformin HCL. The absorbance was measured at $234 \mathrm{~nm}$.

\section{Selection of wavelength}

The wavelength for the analysis of Metformin $\mathrm{HCl}$ (20 ppm) was selected from the UV spectrum. The standard solution of Metformin $\mathrm{HCl}$ was scanned in the range of $200-400 \mathrm{~nm}$ and the $\lambda_{\text {max }}$ was found to be $234 \mathrm{~nm}$ against water shown in Figure 2.

\section{Amount of Metformin in each tablet was calculated by using following formula}

$$
\begin{gathered}
\frac{\text { Sample Absorbance }}{\text { Standard Absorbance }} \times \frac{\text { Standard Dilution }}{\text { Sample Dilution }} \times \text { Average Weight } \\
\% \text { Content }=\frac{\text { Amount Present }}{\text { Label Claim }} \times 100
\end{gathered}
$$

\section{Method validation}

The method was developed and validated according to the analytical procedure as per the $\mathrm{ICH}$ guidelines for validation of analytical procedures in order to determine linearity, accuracy precision, ruggedness, and robustness for the analyte. ${ }^{19,20,21}$

\section{Linearity}

The linearity was evaluated by analyzing the different concentration of the standard solution of Metformin $\mathrm{HCl}$. The Beer-Lambert's concentration range was found to be 10-50 $\mu \mathrm{g} \mathrm{mL}^{-1}$ for Metformin $\mathrm{HCl}$ respectively. The linearity of the relationship between absorbance's and concentration was determined by plotting the calibration curves for Metformin $\mathrm{HCl}$ are shown in Figure 3 and Table 1.

\section{Accuracy (\% Recovery)}

The accuracy study was performed using the standard addition method. ${ }^{22}$ The pre-quantified $2 \mu \mathrm{g} \mathrm{mL}^{-1}$ sample solution of Metformin $\mathrm{HCl}$ were spiked with an extra 80, 120 , and $100 \%$ of the standard Metformin $\mathrm{HCl}$. Absorbances were measured at $234 \mathrm{~nm}$ and the concentration of drug was determined. These mixtures were analyzed by the developed method. The experiment was performed in six times. The percentage recovery of the samples, \% RSD and the percentage were calculated at each concentration level shown in Table 2 .

\section{Precision}

Repeatability measurement was carried out by analyzing six different solutions containing same concentration 20 ppm Metformin $\mathrm{HCl}$ and \% RSD was calculated. Repeatability of the method was established by analyzing various replicates samples of metformin $\mathrm{HCl}$. Precision was carried out by performing interday and intraday variation. In Inter day variation the sample was analyzed on three consecutive days. In an intraday variation in the absorbance was measured three times in a day. Inter and intraday precision was determined using 20 ppm concentration.

\section{Intraday Precision}

In the intraday variation study was determined for a solution $(20 \mathrm{ppm})$ and was analyzed three times for the consecutive days (i.e. morning, afternoon, evening). Mean, standard deviation and \% RSD was calculated and shown in Table 3.

\section{Interday Precision}

The interday precision was determined for a solution $(20 \mathrm{ppm})$ and was analyzed for the three times on a different day. \% RSD was calculated shown in Table 4. 


\section{Ruggedness}

The ruggedness of the method was determined by carrying out the analysis by the different analyst in different laboratories using different UV spectrophotometer and the respective absorbance of $20 \mathrm{mg} \mathrm{mL}^{-1}$ was noted. \% RSD was calculated. The Ruggedness data and analytical performance parameters of Metformin $\mathrm{HCl}$ were shown in Table 5.

\section{Robustness}

The robustness was carried out to evaluate the influence of a small but deliberate variation in the spectrometric condition for determination of Metformin $\mathrm{HCl}$ bulk and tablet dosage form. The Robustness data for variations in wavelength of detections $( \pm 5 \mathrm{~nm})$ and the absorbance and its analytical performance parameters of Metformin $\mathrm{HCl}$ were shown in Table 6.

\section{RESULT AND DISCUSSION}

To optimize the UV parameters, several conditions were tried to achieve a good absorption and peak shape for Metformin HCl. Several solvents of different compositions were tried to provide sufficient selectivity towards the drugs. Distilled water components resulted in better sensitivity.

The methods discussed in the present work provide a convenient and accurate way for the analysis of Metformin $\mathrm{HCl}$ from bulk and tablet dosage form by UV Spectrophotometry method. The $234 \mathrm{~nm}$ wavelength was selected for analysis of Metformin $\mathrm{HCl}$ (Figure 2). The absorbance of Metformin $\mathrm{HCl}$ was found to be 1.102 to 5.710 (Table 1). Selected methods linearity was observed in the concentration range of $10-50 \mathrm{mg} \mathrm{mL}^{-1}$. In this method, the concentration of the drug was determined at $234 \mathrm{~nm}$ using the respective absorptivity value shown in Figure 3.

A Linear correlation was obtained between absorbance Vs concentration. Calibration curve for Metformin $\mathrm{HCl}$ showed linearity in the concentration range $10-50 \mathrm{mg}$ $\mathrm{mL}^{-1}$. The linearity of the calibration curve was validated by the value of correlation coefficients $(r 2)$. The value

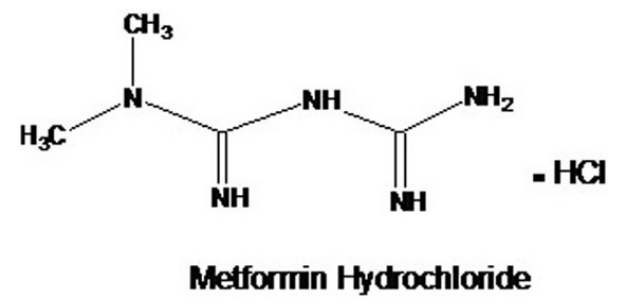

Figure 1: Structure of Metformin of correlation coefficient for Metformin $\mathrm{HCl}$ was found to be 0.9998 shown in Table 1 and Figure 3.

The standard addition method was employed for accuracy measurement. The percentage recoveries for Metformin $\mathrm{HCl}$ were found in the range of 99-101\%. The values of the recovery ( $\%$ ) and $\%$ RSD were shown in Table 2 , which indicates the accuracy of the proposed method.

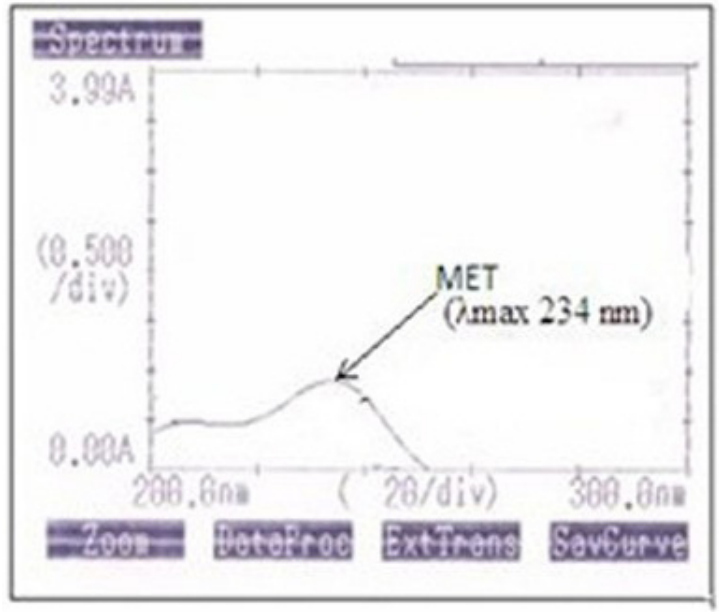

Figure 2: UV Spectrum of Metformin

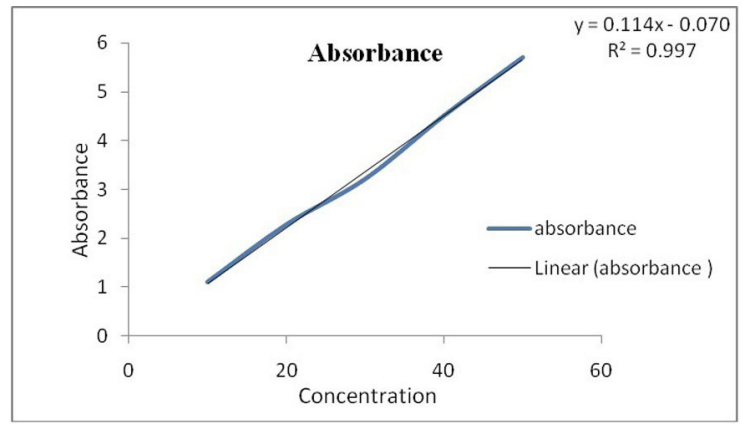

Figure 3: Calibration curve of Metformin at $234 \mathrm{~nm}$

\begin{tabular}{|c|c|c|}
\hline Sr.No. & Concentration (ppm) & Absorbance \\
\hline 1 & 10 & 1.102 \\
\hline 2 & 20 & 2.280 \\
\hline 3 & 30 & 3.215 \\
\hline 4 & 40 & 4.541 \\
\hline 5 & 50 & 5.710 \\
\hline \multicolumn{2}{|r|}{ Mean } & 3.3696 \\
\hline \multicolumn{2}{|r|}{ SD } & 1.8167 \\
\hline \multicolumn{2}{|r|}{ RSD } & 0.5390 \\
\hline \multicolumn{2}{|r|}{ \%RSD } & 53.90 \\
\hline \multicolumn{2}{|c|}{ Correlation coefficient } & 0.9998 \\
\hline \multicolumn{2}{|r|}{ Slope } & 0.07877 \\
\hline
\end{tabular}




\begin{tabular}{|c|c|c|c|c|c|c|}
\hline $\begin{array}{l}\text { Sr. } \\
\text { No. }\end{array}$ & $\begin{array}{l}\text { Concentration } \\
\text { (ppm) }\end{array}$ & Absorbance & Mean & SD & RSD & \%RSD \\
\hline \multirow{3}{*}{1} & \multirow{3}{*}{$80 \%$} & 3.810 & \multirow{3}{*}{3.795} & \multirow{3}{*}{0.01322} & \multirow{3}{*}{0.00348} & \multirow{3}{*}{0.34} \\
\hline & & 3.790 & & & & \\
\hline & & 3.785 & & & & \\
\hline \multirow{3}{*}{2} & \multirow{3}{*}{$120 \%$} & 4.250 & \multirow{3}{*}{4.269} & \multirow{3}{*}{0.01778} & \multirow{3}{*}{0.00416} & \multirow{3}{*}{0.41} \\
\hline & & 4.285 & & & & \\
\hline & & 4.273 & & & & \\
\hline \multirow{3}{*}{3} & \multirow{3}{*}{$100 \%$} & 3.913 & \multirow{3}{*}{3.947} & \multirow{3}{*}{0.04650} & \multirow{3}{*}{0.01170} & \multirow{3}{*}{1.17} \\
\hline & & 4.000 & & & & \\
\hline & & 3.928 & & & & \\
\hline
\end{tabular}

\begin{tabular}{|c|c|c|c|c|}
\hline Sr. No & Conc.(ppm) & Abs-I & Abs-II & Abs-III \\
\hline 1 & 20 & 2.232 & 2.231 & 2.199 \\
\hline 2 & 20 & 2.222 & 2.260 & 2.251 \\
\hline 3 & 20 & 2.251 & 2.260 & 2.251 \\
\hline 4 & 20 & 2.260 & 2.197 & 2.257 \\
\hline 5 & 20 & 2.257 & 2.251 & 2.260 \\
\hline 6 & 20 & 2.255 & 2.195 & 2.226 \\
\hline \multirow{4}{*}{\multicolumn{2}{|c|}{$\begin{array}{c}\text { Average } \\
\text { SD } \\
\text { RSD } \\
\% R S D\end{array}$}} & 2.2451 & 2.2253 & 2.2421 \\
\hline & & 0.0147 & 0.0336 & 0.0247 \\
\hline & & 0.0065 & 0.0151 & 0.0110 \\
\hline & & 0.65 & 1.50 & 1.10 \\
\hline \multicolumn{2}{|c|}{ Average \%RSD } & \multicolumn{3}{|c|}{1.08} \\
\hline
\end{tabular}

\begin{tabular}{|c|c|c|c|c|}
\hline \multicolumn{5}{|c|}{ Table 4: Interday Precision for Metformin (n= 6). } \\
\hline Sr. No & Conc.(ppm) & Day I & Day II & Day III \\
\hline 1 & 20 & 2.232 & 2.270 & 2.280 \\
\hline 2 & 20 & 2.222 & 2.260 & 2.275 \\
\hline 3 & 20 & 2.251 & 2.265 & 2.277 \\
\hline 4 & 20 & 2.260 & 2.281 & 2.280 \\
\hline 5 & 20 & 2.251 & 2.280 & 2.261 \\
\hline 6 & 20 & 2.255 & 2.278 & 2.271 \\
\hline \multicolumn{7}{r}{} & Average & 2.245 & 2.251 & 2.272 \\
\hline & SD & 0.0150 & 0.0086 & 0.0066 \\
\hline & RSD & 0.0066 & 0.0038 & 0.029 \\
\hline & \%RSD & 0.66 & 0.38 & 0.29 \\
\hline
\end{tabular}

The precision of the method was determined by analyzing the drug formulation by replicate injections and precision of the system was determined by mixed standard solutions. \% RSD of the analyte was found to be within the limit of $2 \%$, shown in Table 3 and Table 4 thus the developed method was found to be in the high degree of precision. The low values of the $\%$ RSD indicate the repeatability of the proposed method. ${ }^{23}$

Ruggedness was determined by performing the assay with the same condition on different days, by different analysts, different instrument and different time. ${ }^{24}$ The test results were found within limit $99-101 \%$ shown in Table 5. 
Table 5: Statistical Validation for Ruggedness studies of Metformin.

\begin{tabular}{|c|c|c|c|}
\hline Sr. No & Parameter & Set I & Set II \\
\hline 1 & System & Shimadzu-1700 & Systronics -119 \\
\hline 2 & Sample & Batch No-X & Batch No - Y \\
\hline 3 & Day & Monday & Tuesday \\
\hline 4 & Date & $30 / 01 / 2017$ & $31 / 01 / 2017$ \\
\hline 5 & Time & $11.45 a m$ & $3.45 \mathrm{pm}$ \\
\hline 6 & Lab & Analysis & Chemistry \\
\hline 7 & Analyst & Dange Y. D. & Honmane S. M. \\
\hline 8 & Sample & 20 ppm & 20 ppm \\
\hline 9 & Absorbance & 2.286 & 2.280 \\
\hline 10 & Assay & $99.65 \%$ & $99.85 \%$ \\
\hline
\end{tabular}

\begin{tabular}{|c|c|c|c|c|c|c|c|c|c|}
\hline Sr.No & Set. No & Wavelength (nm) & $\begin{array}{l}\text { Conc. } \\
\text { ( } \mu \mathrm{g} / \mathrm{ml})\end{array}$ & Absorbance & $\begin{array}{c}\text { Average } \\
\text { Abs }\end{array}$ & STDEV & RSD & $\%$ RSD & $\%$ Assay \\
\hline 1 & \multirow{3}{*}{ I } & 239 & 20 & 1.927 & \multirow{3}{*}{1.929} & \multirow{3}{*}{0.002} & \multirow{3}{*}{0.0010} & \multirow{3}{*}{1.03} & \multirow{3}{*}{97.98} \\
\hline 2 & & 239 & 20 & 1.931 & & & & & \\
\hline 3 & & 239 & 20 & 1.929 & & & & & \\
\hline 4 & \multirow{3}{*}{$\|$} & 234 & 20 & 2.199 & \multirow{3}{*}{1.888} & \multirow{3}{*}{0.019} & \multirow{3}{*}{0.0100} & \multirow{3}{*}{1.00} & \multirow{3}{*}{98.10} \\
\hline 5 & & 234 & 20 & 2.185 & & & & & \\
\hline 6 & & 234 & 20 & 2.170 & & & & & \\
\hline 7 & \multirow{3}{*}{ III } & 2029 & 20 & 2.150 & \multirow{3}{*}{2.154} & \multirow{3}{*}{0.014} & \multirow{3}{*}{0.0069} & \multirow{3}{*}{0.60} & \multirow{3}{*}{98.02} \\
\hline 8 & & 229 & 20 & 2.157 & & & & & \\
\hline 9 & & 229 & 20 & 2.154 & & & & & \\
\hline
\end{tabular}

Robustness was determined by carrying out the assay during change wavelength. The $\%$ RSD was found to be not more than $2 \%$ which was within the limit shown in Table 6.

\section{CONCLUSION}

The proposed method quantitatively evaluated in terms of linearity, accuracy, precision, ruggedness, robustness and recovery. All these factors lead to the conclusion that the proposed UV-Spectrophotometric method is simple, accurate, precise, sensitive and cost-effective. This method was adopted for the use of economical and easily available mobile phase and for the UV detector. Thus the used mobile phase makes it an excellent method for the estimation of Metformin $\mathrm{HCl}$ in bulk drug and its formulations.

\section{CONFLICT OF INTEREST}

The authors confirm that these article contents have no conflict of interest.

\section{ABBREVIATIONS USED}

HCl: Hydrochloride; UV: Ultraviolet; RSD: Relative standard deviation; HPLC: High-performance liquid chromatography; HPTLC: High-performance Thin layer liquid chromatography; LC-MS; liquid chromatography-mass spectroscopy; AMPK: AMP-activated protein kinase.

\section{REFERENCES}

1. Grzybowska M, Bober J, Olszewska M. Metformin - mechanisms of action and use for the treatment of type 2 diabetes mellitus. Postepy Hig Med Dosw online. 2011;6(65): 277-85.

2. Willard $\mathrm{HH}$ and Merritt II. Instrumental method analysis. New Delhi: CBS Publication and Distribution; 2001.

3. Kar M, Choudhury PK. HPLC method for estimation of metformin hydrochloride in formulated microspheres and tablet dosage form. Indian J Pharm Sci. 2009;71(3):318-20.

4. Neelima K, Prasad YR. Analytical method development and validation of metformin, voglibose, glimepiride in bulk and combined tablet dosage. Pharmaceutical Methods. 2014;5(1):27-33.

5. Sowjanya P. RP-HPLC method development of metformin in pharmaceutical dosage form. Research and Reviews: J Pharm Analysis. 2015;4(4):9-20.

6. Anedda A, Rial E, Gonzalez-Barroso MM. Metformin induces oxidative stress in white Adipocytes and raises uncoupling protein 2 levels. J Endocrinol. 2008;199(1):33-40. Doi: 10.1677/JOE-08-0278. 
7. Zhang Z, Radziuk J. Inverse relationship between peripheral insulin removal and action: studies with Metformin. American J Physiology. 2001. 1-9.

8. Trautwein C. and Kummerer K.: Designed incomplete degradation of the type II antidiabeticMetformin, http://www.leuphana.de/fileadmin/user_upload/ Forschungseinrichtungen/iec/files/Poster_Incomplete_degradation_of_the typell_antidiabetic_Metformin.pdf.

9. Tache F, Albu M. Specificity of an Analytical HPLC Assay Method of Metformin Hydrochloride. Revue Roumaine De Chimie. 2007;52(6):603-609.

10. Narasimha Rao D, Chandana M. Method Development and Validation of RP-HPLC Method for Simultaneous Analysis of Three-Component Tablet Formulation containing Metformin Hydrochloride, Pioglitazone Hydrochloride, and Glibenclamide. Int J Pharm Tech Research. 2012;4(3):948-956.

11. Dhabale PN, Seervi CR. Simultaneous UV Spectrophotometry Method for Estimation of Gliclazide and Metformin Hydrochloride in Tablet Dosage Form. Int J Chem Tech Res. 2010;2(2):813-17.

12. Dhakar RC, Maurya SD, Aggarwal S, Kumar G, Tilak VK. Design and Evaluation of SRM Microspheres of Metformin Hydrochloride. Int J Comprehensive. 2010;1(7):1-5.

13. Bhinge SD, Malipatil SM, Jondhale A, Hirave R, Savali AS. A new approach to the RP-HPLC method for simultaneous estimation of Atorvastatin calcium and Fenofibrate in pharmaceutical dosage forms. J Chemistry. 2012;9(3):1223-29.

14. Dey S, Reddy YV, Swetha B, Kumar SD, Murthy PN, Sahoo SK, Kumar D, Patro SS, Mohapatra S. Method development and validation for the estimation of Olopatadine in bulk and pharmaceutical dosage forms and its stress degradation studies using UV-VIS Spectrophotometric method. Int J Pharm and Pharmaceutical Sci. 2010;2(4):212-18.

15. Sandhu GS, Hallan SS, Kaur B. Development of RP-HPLC method for simultaneous estimation of glimepiride, Pioglitazone hydrochloride and metformin hydrochloride in a combined tablet dosage form. World J Pharm and Pharmaceutical Sci. 2016;5(3):1278-85

16. Sethuraman S, Adhakrishnan K, Venkateswarlu V, Sravani M, Ramathulasi G, Bhanuteja S. Estimation And Degradation Monitoring Of Cefadroxil In Pharmaceutical Dosage Form By Using UV-Spectroscopy. Asian Journal of Research in Biological and Pharmaceutical Sciences. 2014; 2(1):27-33.

17. Karkhanis VV, Anand Kumar DC, Patel P. Development and Validation of UV Spectrophotometric Method for Estimation of Glipizide in Bulk and Pharmaceutical Dosage Forms. Int J Pharmaceutical Science and Res. 2013;4(5):1865-67.

18. Dey S, Kalyani K, Samyuktha B, Sahoo SK, Mohapatra S, Murthy PN, Kumar D. Development And Validation Of A UV-Vis Spectrophotometric Method For The Estimation And Degradation Monitoring of Cefadroxil In Bulk And Pharmaceutical Dosage Forms. Int J Chem Res. 2010;1(1):29-34.

19. Chatwal GR and Sham KA. Instrumental method of chemical analysis. $5^{\text {th }}$ ed. Mumbai: Himalaya Publishing House; 2002;626-636.

20. Beckett AH and Stenlake JB. The Practical Pharmaceutical Chemistry. Part II. New Delhi: CBS Publishers and Distributors; 1997.

21. Lloyd RS, Joseph JK, Joseph LG. Practical HPLC Method Development. $2^{\text {nd }}$ ed. York: Wiley Wiley-Interscience publication; 1997.

22. Bhinge SD, Malipatil SM. Development and validation of stability indicating the method for simultaneous estimation of cefixime and dicloxacillin using a RP-HPLC method. J Taibah University for Science. 2016;10:734-744.

23. Bhinge SD, Malipatil SM, Sonawane LV. Bioanalytical Method Development and Validation for Simultaneous estimation of cefixime and dicloxacillin in Human Plasma. Acta Chimica Slovenica. 2014;61(3):582-586.

24. Bhinge SD, Malipatil SM, Sonawane LV. Simultaneous estimation of cefixime and cloxacillin in human plasma by Reverse Phase HPLC with UV detection. Thia J Pharm Res. 2012;36:63-71.

\section{PICTORIAL ABSTRACT}

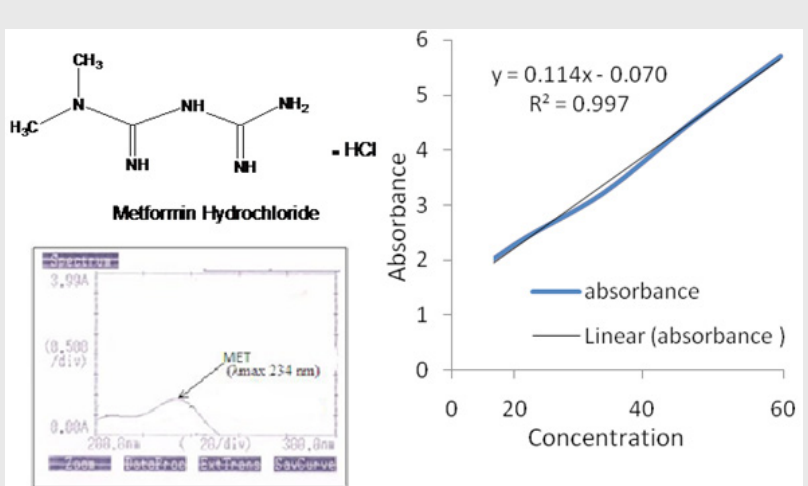

\section{SUMMARY}

- UV/VIS method has been developed and validated for Metformin Hydrochloride. The Linearity was observed in the concentration range of $10-50 \mathrm{mg}$ mL-1 for Metformin Hydrochloride. The correlation coefficients were found to be 0.9998. The percentage recoveries for Metformin Hydrochloride were found in the range of 99-101 \%. Method was quantitatively evaluated in terms of linearity, accuracy, precision, ruggedness, robustness and recovery. The method was simple, convenient and suitable for the determination of Metformin Hydrochloride from bulk and tablet dosage forms.

\section{About Authors}

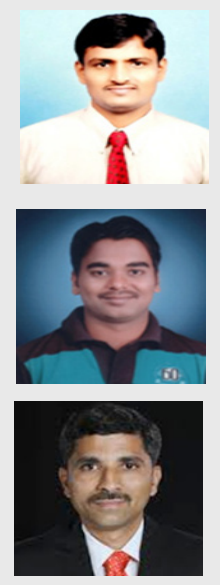

Mr. Sandip M. Honmane: M. Pharm. Asst. Professor at Annasaheb Dange College of B. Pharmacy, Ashta, Sangli (MS). He had total 5 years of experience amongs that 3 years industrial experience in Multinational pharmaceutical companies. He has $>7$ International and national Publications and one book on his credits.

Mr. Yuvraj D Dange: M. Pharm. Asst. Professor at Annasaheb Dange College of Pharmacy, Ashta, Sangli (MS). He has $>5$ International and national Publications.

Dr. Somnath D. Bhinge: M. Pharm Ph.D. Professor \& HOD at Rajarambapu college of Pharmacy Kasegaon, Sangli (MS). He had 9 years in teaching experience. He is Approved PG Teacher. He has $>20$ International and national Publications. He is a Life member of various professional associations like IPA, APTI \& IPS. 


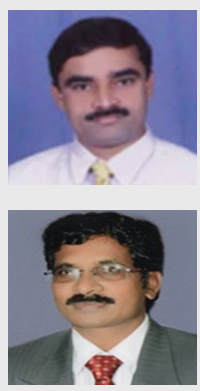

Dr. Vijay R. Salunkhe: M. Pharm. Ph.D. Professor \& HOD at Rajarambapu college of Pharmacy Kasegaon, Sangli (MS). He had 22 years in teaching experience. He is Approved PG Teacher and Ph.D Guide. He has > 32 International and national Publications. He is a Life member of various professional associations like IPA, APTI \& IPS.

Dr. Dhanraj R. Jadge: M. Pharm. Ph.D. Professor and Principal at Annasaheb Dange College of B. Pharmacy, Ashta, Sangli (MS). He had 24 years in teaching experience. He is Approved PG Teacher and Ph.D Guide. He has > 20 International and national Publications. He is a Life member of various professional associations like IPA, APTI \& IPS.

Cite this article: Dange YD, Honmane SM, Bhinge SD, Salunkhe VR, Jadge DR. Development and Validation of UV-Spectrophotometric Method for Estimation of Metformin in Bulk and Tablet Dosage Form. Indian $\mathrm{J}$ of Pharmaceutical Education and Research. 2017;51(4S):S754-S60. 